\title{
DAYA MAKAN, DIAPAUSE DAN MOBILITAS KEONG MAS (POMACEA CANALICULATA) PADA BERBAGAI KEDALAMANAIR
}

\author{
Jacqualine Arriani Bunga ${ }^{1}$, Franciskus Xaverius Wagiman², Witjaksono² ${ }^{2}$ \& \\ Jafendi Hasoloan Purba Sidadolog ${ }^{3}$ \\ ${ }^{1}$ Politeknik Pertanian Negeri Kupang \\ Jl. Adisucipto, Penfui Kupang 85011 \\ ${ }^{2}$ Program Studi Ilmu Pertanian, Minat Ilmu Hama Tumbuhan, Fakultas Pertanian UGM \\ ${ }^{3}$ Program Studi Ilmu Peternakan, Minat Nutrisi dan Makanan Ternak, Fakultas Peternakan UGM \\ Bulaksumur Yogyakarta 55281 \\ E-mail: jacqualinebunga@gmail.com; wagimanfx@ugm.ac.id
}

\begin{abstract}
Feeding rate, aestivation and mobility of golden snails (Pomacea canaliculata) at different depths of water. The research was studied in Malaka District, East Nusa Tenggara Province, during the dry and the rainy season (October 2014 - March 2015). Studies on capacity of damage to the Ciherang rice seedlings were carried out for three weeks. The size of snails used in this experiment was 11-20;21-30; and 31-40 mm. The numbers of seedlings that were planted were 3, 6, 9, 12, 15, 18 and 21 seeds. The treatments were repeated 5 times. The numbers of seeds which are damaged by the snails then were tabulated and analyzed. Snails with the size of 11-20 mm damaged the seeds in 31.67\%, followed by snails with the size of 21-30 mm and 31$40 \mathrm{~mm}$ with potency of damaging were $64.76 \%$ and $97.38 \%$, respectively. The size of snails affects the level of damage to rice seedlings when transplanting. Study about aestivation was conducted in five villages, namely Kamanasa, Wehali, Umakatahan, Harekakae and Kletek when the rice fields were fallow. The observation point was observed at the corner of the dike and along the dike, evaluated every 10 meters away. The results showed snails aestivate when the fields were dry. Studies on snail's mobility conducted on the experiment arena on the mud in buckets, which planted with 20 paddy seedlings. The treatment depth of puddles in the experiment were without puddles, half, the same height and twice the height of snails shell. The treatments were repeated 10 times. Measurement of snail's mobility was performed routinely every 2 hours, observed from the beginning when the snails were placed for 24 hours in advance. The results showed that the depth of the water significantly affected the mobility of snails. Without puddles, the mobility of snails was severely hampered in the mud. The mobility of the juvenile was significantly higher than the imago. The implication of this study was benefit to that the regulating the level of water in the paddy field which is known as an appropriate effective technology and for controlling the attack of the golden snails.
\end{abstract}

Key words: aestivation, feeding rate, mobility, paddy, Pomacea canaliculata

\begin{abstract}
ABSTRAK
Daya merusak, diapause dan mobilitas keong mas (Pomacea canaliculata) pada berbagai kedalaman air. Penelitian dilaksanakan di Kabupaten Malaka, Provinsi Nusa Tenggara Timur selama musim kemarau dan musim penghujan (Oktober 2014 - Maret 2015). Kajian daya makan keong mas dilakukan terhadap bibit padi varietas Ciherang berumur tiga minggu. Keong mas uji berukuran 11-20 mm, 21-30 mm dan 31-40 mm. Jumlah bibit dalam perlakuan 3, 6, 9, 12 , 15, 18 dan 21 bibit, diulang 5 kali. Banyaknya bibit yang dirusak oleh keong mas ditabulasi dan dianalisis. Keong mas ukuran 11-20 mm merusak bibit 31,67\%, ukuran 21-30 mm merusak 64,76\% dan ukuran 31-40 mm merusak 97,38\%. Ukuran keong mas berpengaruh terhadap tingkat kerusakan bibit padi pada saat pindah tanam. Kajian diapause keong mas dilakukan di lima desa yaitu Desa Kamanasa, Wehali, Umakatahan, Harekakae dan Kletek, saat sawah dalam keadaan bero. Jarak antara setiap titik pengamatan adalah 10 meter. Hasil kajian menunjukkan keong mas berdiapause ketika sawah dalam keadaan kering. Kajian mobilitas keong mas dilakukan pada arena percobaan berupa lumpur dalam ember, yang ditanami 20 bibit padi. Perlakuan kedalaman genangan air yaitu tanpa genangan, separuh, sama tinggi dan dua kali tinggi cangkang keong mas, diulang 10 kali. Jarak tempuh mobilitas keong mas diukur rutin setiap 2 jam, selama sehari. Mobilitas keong mas sangat terhambat pada lumpur tanpa genangan air. Mobilitas signifikan lebih tinggi pada keong mas juvenile daripada imago. Implikasi hasil kajian ini adalah pengaturan kedalaman air genangan sawah merupakan teknologi yang tepat dan efektif untuk pengendalian hama keong mas.
\end{abstract}

Kata kunci: daya makan, diapause, mobilitas, padi, Pomacea canaliculata 


\section{PENDAHULUAN}

Keong mas (Pomacea canaliculata) telah menyerang sebagian besar lahan basah di Asia Tenggara selama beberapa dekade terakhir. Survei di Thailand menunjukkan bahwa kepadatan populasi keong mas yang tinggi menyebabkan terjadinya pergeseran ekosistem. Serangan keong mas menyebabkan berkurangnya jumlah tanaman air, terjadinya konsentrasi nutrisi dan biomassa fitoplankton yang tinggi, dan adanya dominasi alga planktonik. Keong mas memicu perubahan ekosistem yang awalnya air jernih dan didominasi makrofita, menjadi keruh dan didominasi alga planktonik. Pergeseran ini sangat merugikan fungsi ekosistem lahan basah (Carlsson et al., 2004).

Di Nusa Tenggara Timur, keong mas dilaporkan telah berada di Flores, Sumba, Rote, Sabu dan Timor. Banyak spesies air tawar yang telah menjadi invasif dan beberapa telah menyebabkan dampak lingkungan yang luas dan membahayakan secara ekonomi (Pimentel et al., 2005). Hal ini dapat dimaklumi karena P. canaliculata memang dikenal sebagai salah satu dari seratus spesies paling invasif di dunia (Lowe et al., 2000; Joshi, 2005). Bunga et al. (2016) menyatakan keberadaan keong mas di permukaan lumpur dan di dalam lumpur tidak berbeda pada siang maupun malam hari $(\mathrm{P}=0,1270)$. Sebagian besar keong mas aktif pada malam hari $(63,20 \%)$ sedangkan pada siang hari sebanyak $22,92 \%$. Sebaliknya keong mas lebih banyak pasif pada siang hari $(77,08 \%)$ daripada malam hari $(36,80 \%)$. Aktivitas keong mas meliputi mobilitas (siang 5,70\%; malam 29,58\%), makan (siang $13,33 \%$; malam $22,50 \%$ ), mating (siang 3,89\%; malam $10,56 \%$ ) dan bertelur (siang $0 \%$ dan malam $0,56 \%)$.

Pada tahun 2010-2012 terjadi eksplosi keong mas dan menyebabkan kerusakan parah sampai puso, sehingga produksi padi di Kabupaten Malaka turun hingga kurang dari 2 ton/ha. (Fransisco, 2013; komunikasi pribadi). Sebelum tahun 2000 keong mas tidak dikenal di Kabupaten Malaka. Hama ini menjadi ancaman budidaya padi karena perkembangbiakannya yang sangat cepat (Wagiman et al., 2014). Koloni keong mas sebelum tanam didominasi oleh nimfa sebanyak $61,45 \%$, juvenile 30,32\% dan imago 8,23\% (Wagiman et al., 2015). Keong mas berukuran kecil mudah menyebar terikut aliran air irigasi. Air memfasilitasi mobilitas keong mas.

Keong mas sangat rakus dan memakan banyak vegetasi air (Fang et al., 2010). Tumbuhan inang yang disukai adalah yang masih muda dan lunak seperti bibit padi, algae, kangkung, tanaman sayuran, enceng gondok, talas, teratai dan gulma air lainnya (Budiono, 2006,
Matsukura et al., 2013) serta sangat polifag (Memon et al., 2011).

Pengendalian keong mas yang telah dilakukan petani di Kabupaten Malaka antara lain dengan memungut keong mas, mengeringkan sawah setelah padi pindah tanam, dan pengendalian kimia menggunakan moluskisida berbahan aktif fentin asetat, metaldehyde dan niklosamida. Pengendalian ini seperti yang dilakukan di Jepang, yaitu mengeringkan sawah ketika padi baru ditanami, handpicking dan aplikasi moluskisida (Yusa \& Wada, 1999).

Drainase di Kabupaten Malaka kurang baik sehingga sawah tetap tergenang. Fluktuasi kedalaman genangan air diduga berpengaruh terhadap mobilitas keong mas. Penelitian ini bertujuan untuk mengetahui daya merusak berbagai ukuran keong mas pada padi, mengetahui perilaku diapause keong mas pada saat habitatnya mengalami kekeringan dan mengetahui pengaruh kedalaman genangan air terhadap mobilitas keong mas.

\section{METODE PENELITIAN}

Tempat dan Waktu. Penelitian dilakukan di 5 desa yaitu Desa Kamanasa, Desa Wehali, Desa Umakatahan, Desa Harekakae dan Desa Kletek, Kecamatan Malaka Tengah, Kabupaten Malaka, Provinsi Nusa Tenggara Timur pada Februari 2014 - Mei 2015.

Daya Makan. Daya makan keong mas dilakukan terhadap bibit padi varietas Ciherang berumur 3 minggu. Arena percobaan berupa ember berukuran tinggi $22 \mathrm{~cm}$, diameter atas $27 \mathrm{~cm}$ dan diameter dasar $19 \mathrm{~cm}$. Ember diisi lumpur setinggi $15 \mathrm{~cm}$ dan ditanami bibit padi di tengah-tengah ember. Keong mas uji adalah keong dengan ukuran 11-20 mm, 21-30 mm dan 31-40 mm. Perlakuan dalam penelitian ini adalah bibit dengan jumlah 3, 6, 9, 12, 15, 18 dan 21 bibit. Masing-masing perlakuan diulang 5 kali. Keong mas yang dipakai dalam pengujian ini, dilaparkan selama 16 jam mulai dari pukul 18.0010.00 WITA. Persiapan arena uji dilakukan pada pukul 09.00. Pada pukul 10.00 keong mas diletakkan pada jarak $5 \mathrm{~cm}$ dari bibit padi. Pengamatan terhadap daya makan keong mas dilakukan pada pukul 09.00 keesokan harinya. Jumlah bibit padi yang dimakan keong mas dicatat, ditabulasi dan dianalisis dengan Anova pada $\alpha=$ 0,05 dan DMRT pada $\alpha=0,05$.

Perilaku Diapause. Perilaku diapause dilakukan dengan cara menentukan 20 titik pengamatan pada luasan sawah $2000 \mathrm{~m}^{2}$, pada kondisi sawah bero dan kering. Titik 
pengamatan ditentukan pada sudut pematang dan sepanjang pematang setiap jarak $10 \mathrm{~m}$. Pada setiap titik, pematangnya dibongkar dan digali lubang berukuran 30 x $30 \mathrm{~cm}$ dengan kedalaman $25 \mathrm{~cm}$ untuk mengetahui apakah keong mas berdiapause selama sawah mengalami kekeringan. Sampling dilakukan menggunakan metode menyusuri pematang (Gambar 1). Metode ini dipilih, karena pengujian menggunakan metode transek sebelumnya, tidak ditemukan keong mas yang berdiapause. Jika pada titik ke-10 tidak ditemukan keong mas yang sedang berdiapause maka pengamatan dihentikan. Sebaliknya, jika sampai titik ke-10 masih ditemukan keong mas yang berdiapause maka pengamatan dilanjutkan sampai ke titik ke-20.

Kajian mobilitas keong mas dilakukan pada arena percobaan seperti yang digunakan pada kajian daya merusak keong mas. Ember diisi lumpur setinggi $15 \mathrm{~cm}$ dan ditanami 20 bibit padi berumur satu bulan di tengahtengah ember. Keong mas uji adalah stadia juvenile dan imago. Perlakuan kedalaman air yaitu tanpa genangan, genangan setengah tinggi cangkang, genangan sama dengan tinggi cangkang dan genangan dua kali tinggi cangkang keong mas. Masing-masing perlakuan diulang 10 kali. Keong mas diletakkan pertama kali pada pukul 18.00 WITA, dengan posisi $5 \mathrm{~cm}$ dari bibit padi. Tempat keong mas pertama kali diletakkan ditandai dengan lidi setinggi $10 \mathrm{~cm}$, yang telah diberi cat warna merah.
Pengamatan dilakukan rutin setiap dua jam sekali selama satu hari, sehingga terdapat 12 kali pengamatan. Posisi keong mas pada saat pengamatan pertama pada pukul 20.00 WITA ditandai dengan lidi setinggi $10 \mathrm{~cm}$ yang ujungnya diberi cat hijau. Jarak antara lidi merah dan lidi hijau diukur dengan mistar. Mobilitas keong mas diasumsikan arah gerakan lurus sehingga jarak tempuh selama 2 jam merupakan jarak antara dua lidi. Pengamatan-pengamatan berikutnya dilakukan seperti pengamatan pertama dan diakhiri pada pukul 18.00 WITA hari berikutnya. Pengaruh kedalaman air terhadap mobilitas keong mas dianalisis dengan Anova pada $\alpha=$ 0,05 dan DMRT pada $\alpha=0,05$.

\section{HASIL DAN PEMBAHASAN}

Daya Makan. Rata-rata jumlah bibit padi yang diamakan oleh keong mas berturut-turut adalah ukuran 11-20 mm sebanyak 5,6 bibit; ukuran 21-30 mm sebanyak 11,6 bibit dan ukuran 31-40 mm sebanyak 20,6 bibit (Tabel 1).

Persentase jumlah bibit padi yang dirusak oleh keong mas menunjukkan ada perbedaan nyata, $\mathrm{P}<0.0001$. Ukuran keong mas berpengaruh terhadap tingkat kerusakan bibit padi pada saat pindah tanam. Keong mas dengan ukuran 31-40 mm merusak hingga 97,38\%, ukuran 21-30 mm merusak sebanyak $64,76 \%$

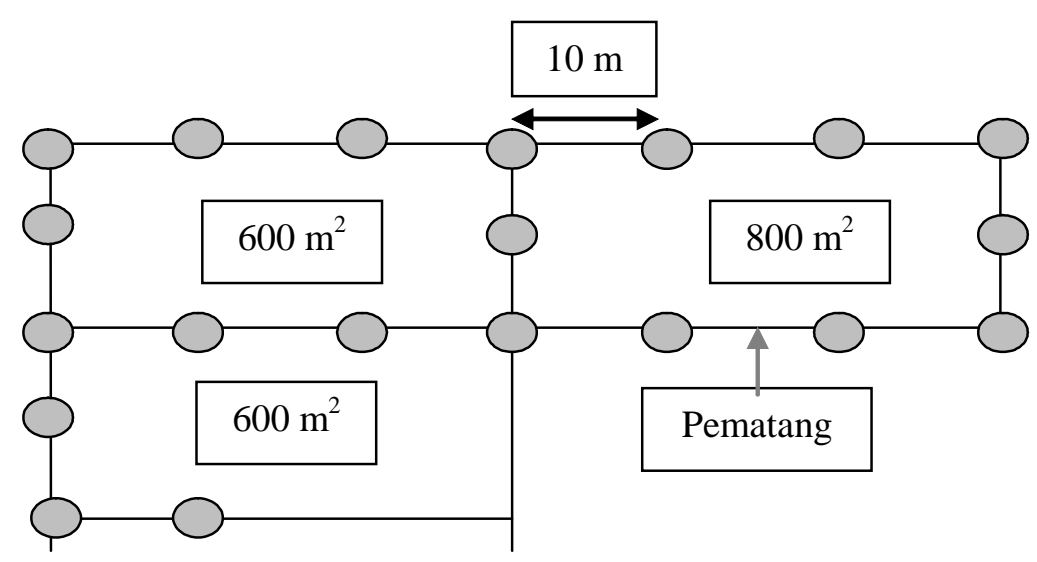

Gambar 1.Model sampling menelusuri pematang

Tabel 1. Daya makan keong mas terhadap bibit padi umur tiga minggu

\begin{tabular}{ccc}
\hline Ukuran Keong Mas $(\mathrm{mm})$ & Jumlah bibit & Rata-rata jumlah bibit yang rusak $(\%) \pm \mathrm{Sd}$ \\
\hline $31-40$ & 20,6 & $97,38 \pm 1,766 \mathrm{a}$ \\
$21-30$ & 11,6 & $64,76 \pm 6,277 \mathrm{~b}$ \\
$11-20$ & 5,6 & $31,67 \pm 2,608 \mathrm{c}$ \\
\hline $\mathrm{t}_{\alpha 0.05}, \mathrm{P}<0.0001$ & & \\
\hline
\end{tabular}


dan ukuran 11-20 mm merusak sebanyak 31,67\%. Semakin besar ukuran keong mas, semakin banyak pula jumlah bibit yang dirusaknya. Jumlah bibit padi yang dimakan keong mas menunjukan ukuran yang paling merusak berturut-turut adalah 31-40 mm; $21-30 \mathrm{~mm}$ dan 11-20 mm (Gambar 2).

Penelitian yang dilakukan Teo (2003), menunjukkan bahwa pada kedalaman air $5 \mathrm{~cm}$, potensi kerusakan yang ditimbulkan oleh keong mas semakin sedikit dengan meningkatnya umur bibit padi. Kerusakan parah bisa terjadi jika populasi keong mas di lapangan tinggi. Karena itu pengetahuan tentang daya merusak keong mas berbagai ukuran ini, dapat memberikan informasi bagaimana mengupayakan pengendalian yang efektif dengan mengatur jumlah populasi keong di persawahan pada taraf yang tidak merusak secara ekonomi.

Perilaku Diapause. Perilaku diapause keong mas sangat dipengaruhi oleh kondisi kekeringan di persawahan. Pada kajian ini ditemukan keong mas yang tertutup operculum ketika berdiapause. Kondisi diapause keong mas menunjukkan bahwa air merupakan faktor utama dalam mendukung aktivitas keong mas.
Sedikitnya keong mas yang ditemukan berdiapause pada kedalaman $25 \mathrm{~cm}$ di bawah pematang (Tabel 2), karena kondisi sawah terlampau kering sehingga diduga keong mas membenamkan diri lebih dalam lagi mencapai tanah lembab. Hal ini dibuktikan pada saat pembongkaran pematang ditemukan banyak cangkang keong mas yang telah kosong. Kemungkinan jika dilakukan penggalian lebih dalam di bawah pematang hingga mencapai tanah lembab, bisa ditemukan keong mas yang berdiapause. Namun untuk membuktikannya perlu ada penelitian lanjutan.

Di daerah subtropis (Buenos Aires), keong mas aktif bereproduksi pada awal musim semi (Oktober) sampai akhir musim panas (Maret/April). Selanjutnya keong mas berdiapause dengan cara mengubur diri dalam tanah yang lembab dan akan aktif lagi ketika temperatur air naik pada musim semi (Estebenet \& Cazzaniga, 1992). Berbeda dengan kondisi Kabupaten Malaka, keong mas aktif bereproduksi pada bulan Januari sampai Juni dimana air cukup tersedia karena musim hujan, ada beberapa sumber mata air dan pengairan dari bendungan Benenain. Selanjutnya pada bulan Juli sampai Desember, keong mas mulai

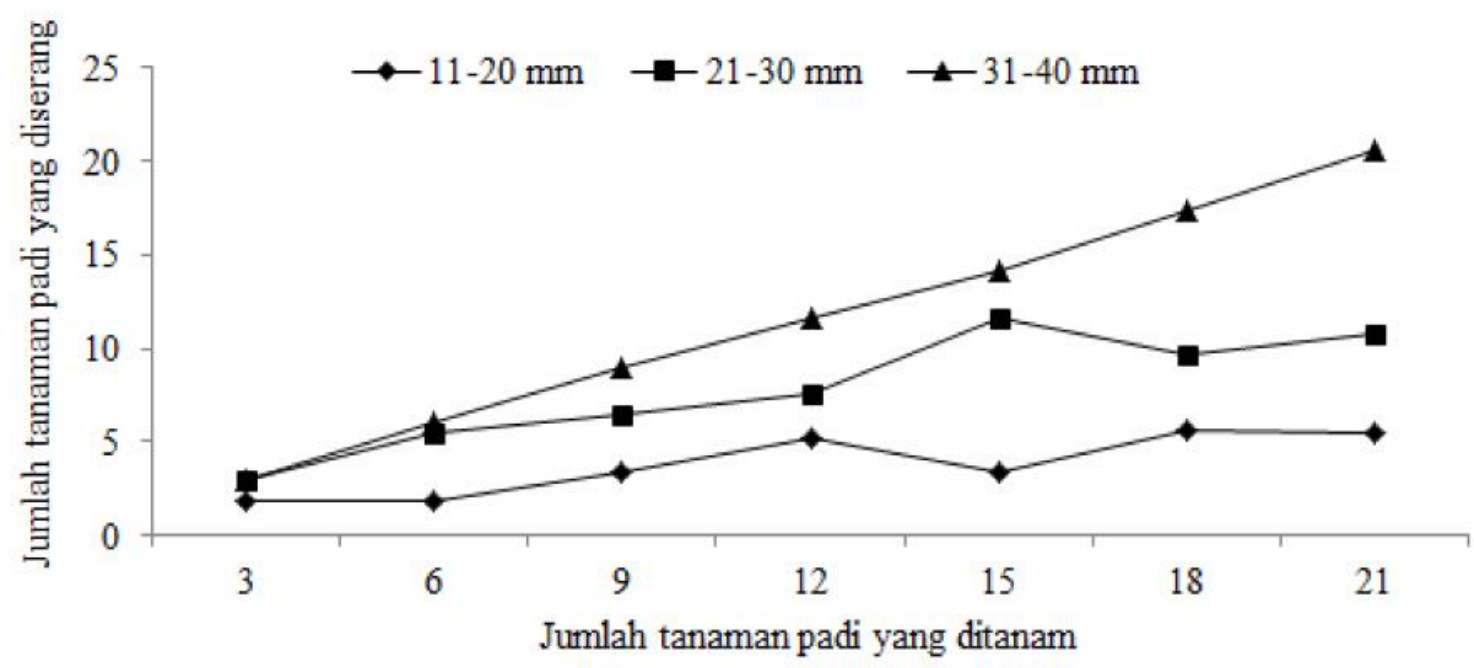

Gambar 2. Jumlah bibit padi yang diserang berdasarkan ukuran keong mas: (a). 31-40 mm; (b) 21-30 mm; (c). 11$20 \mathrm{~mm}$

Tabel 2. Jumlah keong mas imago yang ditemukan

\begin{tabular}{lc}
\hline \multicolumn{1}{c}{ Desa } & Jumlah keong mas imago yang ditemukan (ekor) \\
\hline Kamanasa & 3 \\
Wehali & 1 \\
Umakatahan & 1 \\
Harekakae & 0 \\
Kletek & 1 \\
\hline
\end{tabular}


berdiapause karena persawahan mengalami kekeringan (Gambar 3).

Penelitian yang pernah dilakukan Riani (2010), menunjukkan bahwa kemampuan diapause keong mas fase juvenile memperlihatkan adanya perbedaan. Semakin lama diapause, maka jumlah keong mas yang mati juga semakin meningkat menjadi $67 \%$ dan terjadi penurunan bobot tubuh sejalan dengan lamanya diapause yaitu pada bulan ke enam mencapai $48 \%$.

Mobilitas Keong Mas. Mobilitas keong mas juvenile dipengaruhi sangat signifikan $(\mathrm{P}<0,001)$ oleh kedalaman genangan air. Pada perlakuan lumpur tanpa genangan, mobilitas keong mas terhambat. Pada siang hari selama pukul $12.00-18.00$ WITA, keong mas fase juvenile tidak melakukan mobilitas. Sementara itu pada pukul 20.00 - 06.00 WITA, dalam semua kondisi kedalaman air termasuk lumpur tanpa genangan, keong mas juvenile melakukan mobilitas. Pada pukul 08.00 WITA, mobilitas keong mas juvenile turun drastis. Dalam kondisi gelap pada malam hari, tanpa genangan dan lumpur masih berbentuk seperti pasta, keong mas juvenile masih melakukan mobilitas terbatas sekitar 3,55 cm (Tabel 3 dan Gambar 4). Kedalaman air separuh hingga dua kali tinggi cangkang keong mas tidak berpengaruh signifikan terhadap mobilitas keong mas juvenile. Air memfasilitasi atau memudahkan keong mas bermigrasi. Menurut Havel et al., 2015), keberadaan waduk dapat menjadi sarana yang menyediakan air untuk memudahkan suatu spesies air invasif (AIS=Aquatic Invasive Spesies) menginvasi suatu daerah baru.

Sama halnya dengan fase juvenile, mobilitas keong mas imago juga sangat signifikan $(\mathrm{P}=0,0022)$ dipengaruhi oleh adanya genangan air. Tanpa genangan keong mas imago tidak bergerak sejak pukul 04.00 WITA sampai pukul 18.00 WITA. Namun pada malam hari dan tanpa genangan keong mas imago melakukan mobilitas pada pukul 20.00-02.00 WITA(Gambar 4). Mobilitas keong mas imago difasilitasi oleh tersedianya genangan air dan tidak dipengaruhi oleh kedalaman air genangan (Tabel $3)$.

Mobilitas keong mas juvenile signifikan lebih tinggi dari pada imago. Pada berbagai kedalaman genangan air di atas lumpur, jarak tempuh juvenile lebih jauh daripada imago (Tabel 4).

Keong mas juvenile lebih gesit, hampir dua kali lebih jauh jarak tempuhnya, apalagi jika tersedia air cukup lebih mudah menyebar. Kemampuan bergerak keong
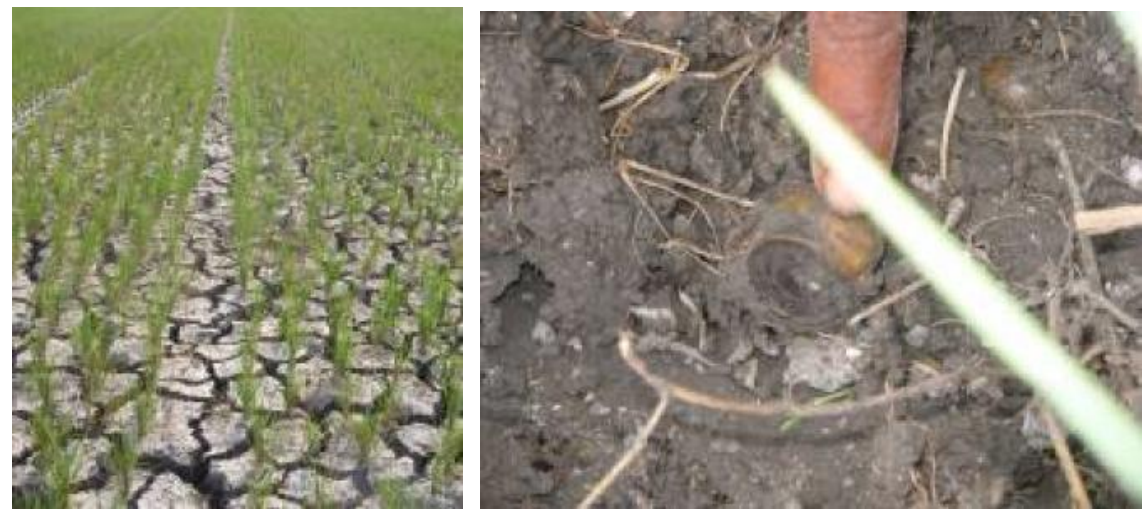

Gambar 3. Persawahan di Kabupaten Malaka pada musim kemarau dan operculum yang menutup cangkang keong mas saat berdiapause

Tabel 3. Pengaruh kedalaman genangan air terhadap jarak tempuh mobilitas keong mas fase juvenile dan imago

\begin{tabular}{|c|c|c|}
\hline \multirow{2}{*}{ Ketinggian Genangan } & \multicolumn{2}{|c|}{ Rerata jarak tempuh $(\mathrm{cm}) \pm \mathrm{SD}$} \\
\hline & Juvenile & Imago \\
\hline Tanpa genangan & $3,55 \pm 3,508 \mathrm{a}$ & $0,95 \pm 1,717 \mathrm{a}$ \\
\hline Genangan separuh tinggi cangkang & $10,36 \pm 2,831 b$ & $4,40 \pm 3,525 b$ \\
\hline Genangan sama dengan tinggi cangkang & $11,26 \pm 2,735 b$ & $6,38 \pm 4,234 b$ \\
\hline Genangan dua kali tinggi cangkang & $10,39 \pm 2,895 b$ & $5,40 \pm 3,743 b$ \\
\hline
\end{tabular}

Angka yang diikuti huruf yang sama dalam kolom, menunjukkan tidak berbeda nyata 
mas sangat tergantung kepada keberadaan air. Keong mas juvenile dan imago tidak aktif bermobilitas setelah permukaan lumpur benar-benar mengering. Fenomena ini dapat dimanfaatkan sebagai upaya pengendalian keong mas dengan cara tidak memberikan genangan pada saat pindah tanam. Pengetahuan tentang kemampuan mobilitas keong mas ini juga mengingatkan petani bahwa ketika memungut keong mas pada sore

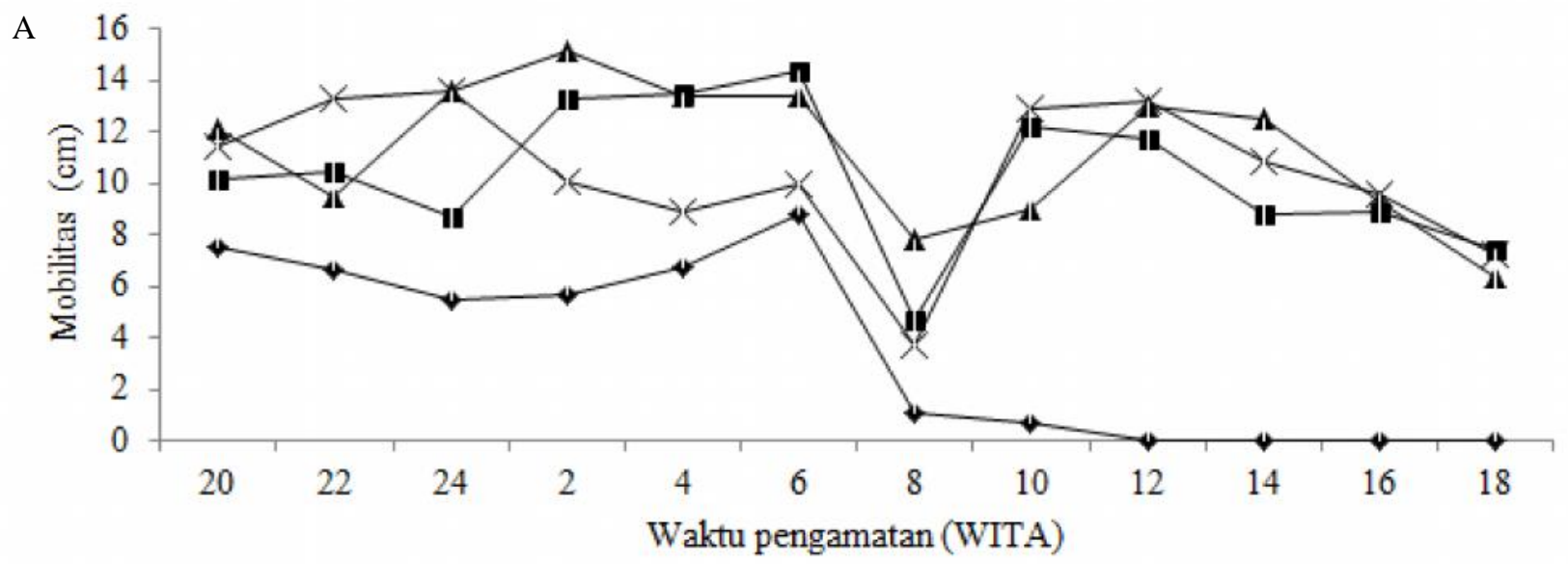

\section{$\rightarrow$ Tanpa genangan \\ Genangan setengah tinggi cangkang \\ $\leftarrow$ Genangan sama dengan tinggi cangkang $\rightarrow$ Genangan dua kali tinggi cangkang}

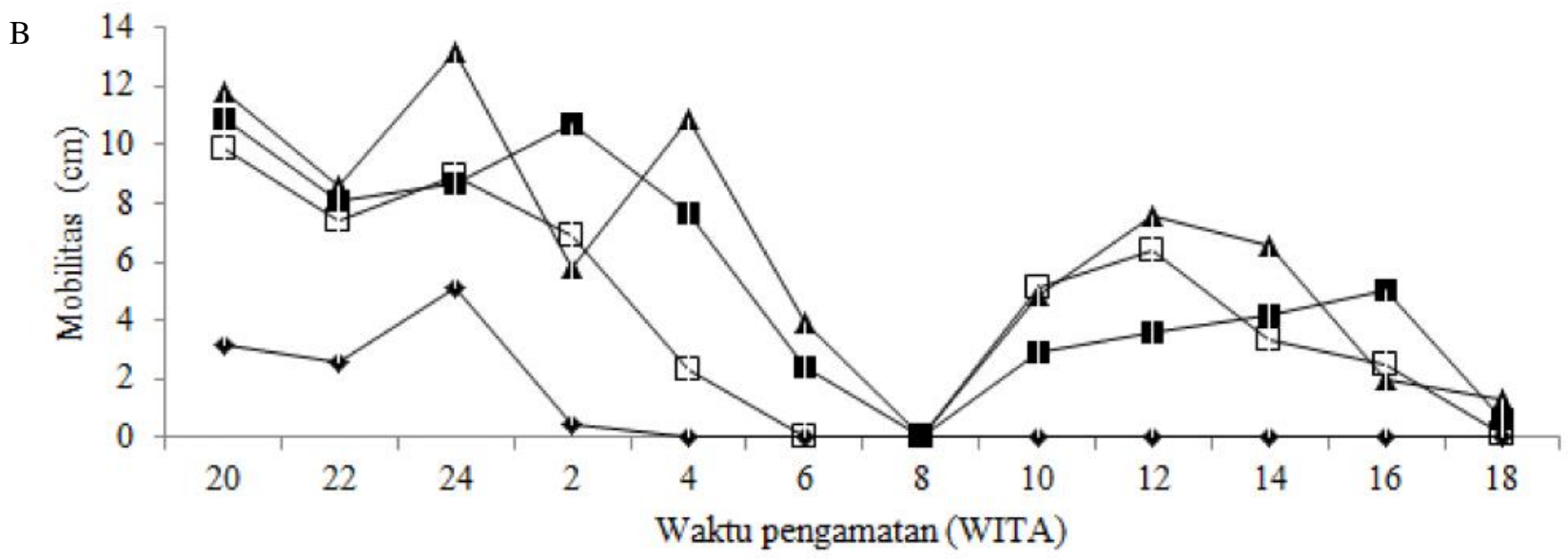

\section{- Tanpa Genangan $\quad \square$ Genangan setengah tinggi cangkang}

$\rightarrow$ Genangan sama dengan tinggi cangkang $\rightarrow-$ Genang an dua kali tinggi cangkang

Gambar 4. Pola mobilitas keong mas, juvenile (A) dan imago (B) pada berbagai kedalaman air

Tabel 4. Pengaruh tinggi genangan terhadap mobilitas keong mas fase juvenile dan imago, setiap dua jam selama sehari

\begin{tabular}{llcc}
\hline \multicolumn{1}{c}{ Ketinggian Genangan } & Fase & Rerata $(\mathrm{cm}) \pm \mathrm{SD}$ & $\mathrm{P}$ \\
\hline Tanpa genangan & Juvenile & $3,55 \pm 3,508$ & 0,0070 \\
& Imago & $0,95 \pm 1,717$ & \\
Genangan separuh tinggi cangkang & Juvenile & $10,36 \pm 2,831$ & 0,0002 \\
& Imago & $4,40 \pm 3,525$ & \\
Genangan sama dengan tinggi cangkang & Juvenile & $11,26 \pm 2,735$ & 0,0002 \\
& Imago & $6,38 \pm 4,234$ & \multirow{2}{*}{0,0002} \\
Genangan dua kali tinggi cangkang & Juvenile & $10,39 \pm 2,895$ & \\
& Imago & $5,40 \pm 3,743$ & \\
\hline
\end{tabular}


hari sebaiknya tidak meletakkannya di atas pematang karena keong mas masih dapat kembali turun ke air.

Habitat keong mas berada di perairan air tawar yang tergenang atau berarus lambat, sampai ketinggian $1000 \mathrm{~m} \mathrm{dpl}$ (LIPI, 1999). Populasi keong mas berkembang dengan baik ditempat-tempat yang tergenang (Budiono, 2006). Pada kedalaman air lebih dari $5 \mathrm{~cm}$, sawah yang ditanami benih langsung, benih pindah tanam umur 21, 39 dan 40 hari, berturut-turut mengalami kerusakan oleh keong mas sebesar 100; 89,2; 59,7 dan $46 \%$. Pada keadaan tanah lembab, mobilitas keong mas menjadi terbatas sehingga mencegah kerusakan padi yang lebih parah (Teo, 2003).

\section{SIMPULAN}

Ukuran keong mas berpengaruh terhadap tingkat kerusakan bibit padi pada saat pindah tanam. Kerusakan parah bisa terjadi jika populasi keong mas di lapangan tinggi. Kekeringan mendorong keong mas mempertahankan hidup pada habitatnya dengan melakukan diapause. Hal ini menunjukkan bahwa air merupakan faktor utama dalam mendukung aktivitas keong mas. Lumpur sawah tanpa genangan air efektif menghambat mobilitas keong mas. Adanya genangan air sampai dua kali tinggi cangkang tidak mempengaruhi jarak tempuh mobilitas keong mas.

\section{SANWACANA}

Penelitian ini bagian dari Disertasi yang dibiayai oleh DIPA UGM, lewat Penelitian Unggulan UGM TA. 2014, Nomor kontrak: LPPM-UGM/391/LIT/2014, tanggal 3 Maret 2014. Ucapan terima kasih disampaikan kepada LPPM UGM, Kelompok Tani dan PEMDA Kabupaten Malaka yang telah membantu kelancaran penelitian.

\section{DAFTAR PUSTAKA}

Budiono S. 2006. Teknik mengendalikan keong mas pada tanaman padi. J. Ilmu-Ilmu Pertanian 2(2): 128133.

Bunga JA, Wagiman FX, Witjaksono \& Jafendi HPS. 2016. Biological clock of golden snail (Pomacea canaliculata) under conditions of Malaka Regency East Nusa Tenggara Province, Indonesia. ARPN J. Agric. and Biol. Sci. 11(4): 127-130.
Carlsson NOL, Bronmark C \& Hansson LA. 2004. Invading herbivory: the golden apple snail alters ecosystem functioning in Asian wetlands. Ecology 85(6): 1575-1580.

Estebenet AL \& Cazzaniga NJ. 1992. Growth and demography of Pomacea canaliculata (Gastropoda: Ampullariidae) under laboratory conditions. Malacological Rev. 25: 1-12.

Fang L, Wong PK, Lin L, Lan C, \& Qiu JW. 2010. Impact of invasive apple snails in Hong Kong on wetland macrophytes, nutrients, phytoplankton and filamentous algae. Freshwater Biol. 55 (6): 1191-1204.

Havel JE, Kovalenko KE, Thomas SM, Amalfitano S \& Kats LB. 2015. Aquatic invasive species: challenges for the future. Hydrobiologia 750(1): 147-170.

Joshi RC. 2005. Managing invasive alien mollusc species in rice. In: Bill Hardy (Ed). Invasion of the alien mollusc. Mini Review 30(2): 5-13. International Rice Research Notes (IRRN), Maligaya, Philippines.

Lowe S, Browne M, Boudjelas S, \& De Poorter M. 2000. 100 of the world's worst invasive alien species: A selection from the global invasive species database. Invasive Species Specialist Group (ISSG), Species Survival Commission (SSC), 10 pp. World Conservation Union (IUCN), New Zealand.

LIPI.1999. Keong dan kerang Sawah. Seri Panduan Lapangan. Puslitbang Biologi-LIPI, Prima Centra Jakarta.

Matsukura K, Okuda M, Cazzaniga NJ, \& Wada T. 2013. Genetic exchange between two freshwater apple snails, Pomacea canaliculata and Pomacea maculate invading East and Southeast Asia. Biol. Invasions. 15: 2039-2048.

Memon UN, Baloch WA, Tunio GR, Burdi GH, Korai AL, \& Pirzada AJ. 2011. Food, Feeding and Growth of Golden Apple Snail Pomacea canaliculata, Lamarck (Gastropoda: Ampullariidae), Department of Fresh Water Biology and Fisheries, University of Sindh, Jamshoro, Institute of Plant Sciences, University of Sindh, Jamshoro. 
Pimentel DR, Zuniga R \& Morrison D. 2005. Update on the environmental and economic costs associated with alien-invasive species in the United States. Ecol. Econ. 52(3): 273-288.

Riani E. 2010. Kemampuan aestivasi keong murbai (Pomacea sp.) stadia juvenil. J. Moluska Indonesia 1: 65-69.

Teo SS. 2003. Damage potential of the golden apple snail Pomacea canaliculata (Lamarck) in irrigated rice and its control by cultural approaches. Int. J. Pest Manage. 49(1): 49-55.

Wagiman FX, Harisma, Triman B \& Ariani JB. 2015. Feeding strategy and feeding capacity of duck (Anas platyrhyncos domesticus) as a predator of golden snail (Pomacea canaliculata). Int. J. Adv. Pharm. Biol. Chem. (IJAPBC) 4(2): 491495.
Wagiman FX, Triman B, Sidadolog JHP, Bunga JA. 2014. Persepsi petani padi terhadap eksplosi hama keong mas di Kabupaten Malaka, Provinsi Nusa Tenggara Timur. In: Jangkung Handoyo Mulyo et al. (Ed). Kedaulatan Pangan dan Pertanian. Prosiding Seminar Nasional Hasil Penelitian Sosial Ekonomi Pertanian, pp. 472-480. Fakultas Pertanian UGM.

Yusa Y \& Wada T. 1999. Impact of the introduction of apple snails and their control in Japan. Naga, The ICLARM Quarterly 22(3): 9-13. 